\title{
Perancangan Interkoneksi Pembangkit Listrik Tenaga Surya 1mwp On-Grid Pada Jaringan Distribusi Cileungsi
}

\author{
Mohammad Hafidz'; Mariya JP² \\ 1,2 Sekolah Tinggi Teknik PLN \\ 1 mhafidz49@gmail.com \\ ${ }^{2}$ mariyajp89@gmail.com
}

\begin{abstract}
Bogor is one of the major cities in Indonesia where electricity demand is increasing rapidly every year. PT Sinar Energi Indonesia has large vacant land plans to build a $1 \mathrm{MW}$ Solar Power Plant (SPP) in the Cileungsi area. This is supported by the location which is close to the Cileungsi substation owned by PLN (800 meters) and also SPP is suitable with the characteristics of the electricity load in the area where the peak load occurs during the day and the development of SPP will reduce pollution caused by thermal plants. Interconnection of SPP with Cileungsi substation requires separate analysis to determine the best interconnection design between SPP and PLN grid. The author will use ETAP 12.6 software for load flow, short circuit and transient analysis so that the interconnection design will not cause harm, both for developers and for PLN. From the simulation results with ETAP 12.6 software does not show a negative impact (small power losses, small voltage drop, and the value of the short circuit current that occurs does not exceed the capacity of the equipment), and if there is a disturbance in the SPP unit, the transient shows within 1 second, the system has stabilized. Beside technical side, the economic point of view from this Solar Power Plant will also have a positive impact with the planned electricity tariff value of 6,884 cent US \$ I $k W h$, still below the local production cost value (West Java 6.91 cent US \$ / kWh, ESDM Ministerial Decree No.55 years 2019). Therefore, this research is expected to be able to help the developer and PLN in interconnection of the Solar Power Plant Cileungsi to PLN grid.
\end{abstract}

Keywords: Solar Power Plant, ETAP, Electricity tarif

\begin{abstract}
ABSTRAK
Bogor merupakan salah satu kota besar di Indonesia dimana kebutuhan listrik meningkat pesat setiap tahunnya. PT Sinar Energi Indonesia memiliki lahan kosong yang luas berencana untuk membangun PLTS dengan kapasitas 1 MW di daerah Cileungsi. Hal ini didukung dengan dekatnya lokasi tersebut ke Gardu Induk Cileungsi milik PLN (800 meter) dan juga PLTS sesuai dengan karakteristik beban listrik daerah tersebut dimana beban puncak terjadi pada siang hari dan pengembangan PLTS akan mengurangi polusi yang diakibatkan pembangkit termal. Interkoneksi PLTS dengan Gardu Induk Cileungsi memerlukan analisis tersendiri untuk menentukan desain terbaik interkoneksi antara PLTS dengan grid PLN. Penulis akan menggunakan bantuan software ETAP 12.6 untuk analisis aliran daya, hubung singkat dan transient sehingga desain interkoneksi tidak akan menyebabkan kerugian baik bagi pengembang maupun bagi PLN. Dari hasil simulasi dengan software ETAP 12.6 tidak menunjukkan dampak negatif (rugi-rugi daya kecil, drop tegangan kecil, dan nilai arus hubung singkat yang terjadi tidak melebihi kapasitas peralatan), serta jika ada gangguan pada unit PLTS, transient menunjukkan dalam waktu 1 detik sistem sudah kembali stabil. Selain dari sisi teknis, dari sisi keekonomian pun PLTS ini akan berdampak positif dengan nilai tarif listrik yang direncanakan yaitu 6.884 cent US\$/kWh, masih di bawah nilai BPP setempat (Jawa Barat 6.91 cent US\$/kWh, Kepmen ESDM No.55 tahun 2019). Maka dari itu, diharapkan penelitian ini dapat membantu pihak pengembang dan juga PLN dalam interkoneksi PLTS Cileungsi ini ke grid PLN.
\end{abstract}

Kata kunci: PLTS, ETAP, Tarif Listrik 


\section{PENDAHULUAN}

Saat ini kebutuhan listrik selalu meningkat dengan pesat khususnya di kota-kota besar seperti Jakarta, Bogor dll. Untuk memenuhi kebutuhan listrik tersebut dibutuhkan pengembangan pembangkit baru. Namun pengembangan pembangkit termal telah dibatasi karena menimbulkan polusi. Hal ini menuntut pengembangan pembangkit energi baru terbarukan (EBT) yang bebas polusi seperti PLTS, PLTA, PLTB dll. PLTS merupakan salah satu opsi pembangkit EBT yang memiliki potensi besar di dunia dimana daya dari energi matahari yang diterima bumi adalah sekitar 1,8 x 1011 MW dimana nilai ini sangat besar untuk memenuhi kebutuhan listrik masyarakat.(1)

Hal tersebut didukung oleh Kementrian ESDM yang telah mengeluarkan Permen No. 50 Tahun 2017 tentang Pemanfaatan Sumber Energi Terbarukan Untuk Penyediaan Tenaga Listrik. Dalam permen tersebut dijelaskan bahwa pemerintah melaksanakan percepatan pencapaian tingkat pemanfaatan energi baru dan terbarukan (EBT) dalam bauran energi untuk peyediaan tenaga listrik dengan mendorong pemanfaatan energi air, biomasa, surya, dan angin untuk pembangkitan tenaga listrik.

Selain Permen di atas, dalam Kebijakan Energi Nasional (KEN) yang tertuang dalam Peraturan Pemerintah Nomor 79 Tahun 2014. KEN diamanatkan target energi yang harus disediakan pada Tahun 2025 adalah 400 juta TOE berdasarkan bauran energi mix: minyak bumi $25 \%$, gas bumi $22 \%$, batubara $30 \%$ dan energi baru terbarukan 23\%. Untuk mencapai target di atas diimplementasikan ke dalam Rencana Umum Energi Nasional (RUEN) dan Rencana Umum Energi Daerah (RUED). RUEN mengatur secara makro mulai dari penyediaan hingga pemanfaatan energi ke setiap sektornya.

Mengacu dari hal tersebut, PT Sinar Energi Indonesia, ingin membantu ketersediaan listrik EBT dengan rencana pembangunan PLTS Cileungsi. PT. Sinar Energi Indonesia (SEI) merupakan perusahaan yang dibentuk sebagai pengemban misi dari perusahaan holding Korindo Group, yang telah lebih dari 10 tahun berkecimpung dalam pengembangan pembangkit tenaga listrik biomasa, dan biogas. Dengan adanya tanah seluas lebih dari 42 Hektar di Cileungsi selama bertahun-tahun yang hanya digunakan untuk pengaturan limbah pabrik, SEI diberikan mandat oleh pimpinan Korindo group untuk membangun proyek PLTS Independent Power Producer (IPP) untuk PT. PLN (Persero). Keberadaan lokasi tanah untuk proyek PLTS ini sangatlah strategis karena dekat dengan gardu induk Cileungsi milik PLN.

PLTS tersebut direncanakan mengirim daya ke grid PLN sebesar 1MW. Maka dari itu, diperlukan analisis interkoneksi PLTS ini ke sistem grid $20 \mathrm{kV}$ PLN yang akan menentukan lokasi titik interkoneksi terbaik bagi PLTS ini ke sistem grid PLN. Analisis interkoneksi ini dapat dilakukan dengan bantuan software ETAP 12.6. Selain dari sisi teknis, sisi ekonomi dari PLTS ini juga akan dibahas secara general. Berdasarkan Kepmen ESDM No.55 tahun 2019, nilai Biaya Pokok Produksi Jawa Barat adalah 6.91 cent US $\$ / k W h$, sedangkan tarif listrik yang direncanakan untuk pengembangan PLTS ini adalah 6.884 cent US $\$ / k W h$. Dari hal ini dapat dilihat bahwa PLTS ini akan ikut andil dalam menurunkan nilai BPP setempat dan juga BPP nasional pada umumnya.

\section{MATERI DAN METODE/PERANCANGAN PENELITIAN}

Perancangan penelitian ini dilakukan dengan melakukan studi literature dan mengumpulkan materi/teori yang dapat digunakan, lalu mengumpulkan data, analisis data, simulasi dan kesimpulan. 


\subsection{Landasan Teori}

Energi surya atau matahari telah dimanfaatkan di banyak belahan dunia dan jika dieksploitasi dengan tepat, energi ini berpotensi menyediakan kebutuhan konsumsi energi dunia saat ini dalam waktu yang lebih lama. Potensi energi surya tersebar di hampir seluruh wilayah Indonesia seperti yang terlihat pada gambar 1 berikut.

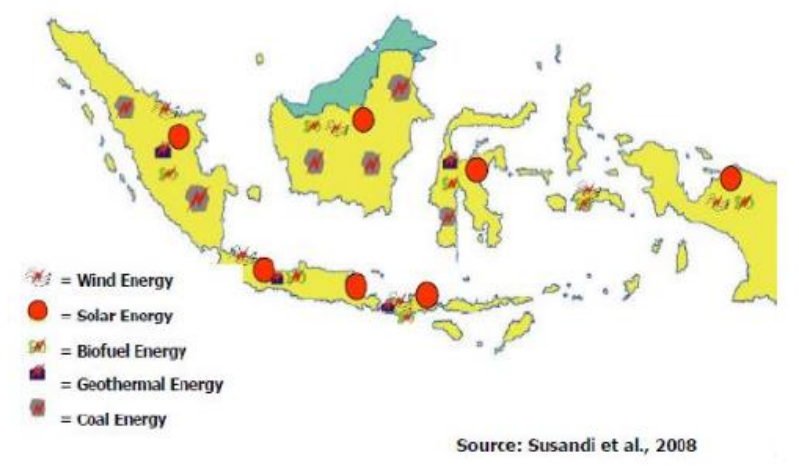

Gambar 1. Potensi Energi Surya di Indonesia (2)

\subsubsection{Komposisi Pembangkit Listrik Tenaga Surya (PV)}

Istilah sel surya mengacu pada perangkat senyawa semikonduktor yang mengubah energi cahaya dari sinar matahari menjadi energi listrik, sedangkan perakitan sel surya disebut sebagai modul. String adalah beberapa modul yang dihubungkan bersama dalam rangkaian atau koneksi paralel untuk mendapatkan tegangan dan output yang diinginkan. Array adalah kumpulan beberapa string dalam koneksi paralel untuk memungkinkan koneksi dengan grid. Hal ini dapat digambarkan sebagai berikut.

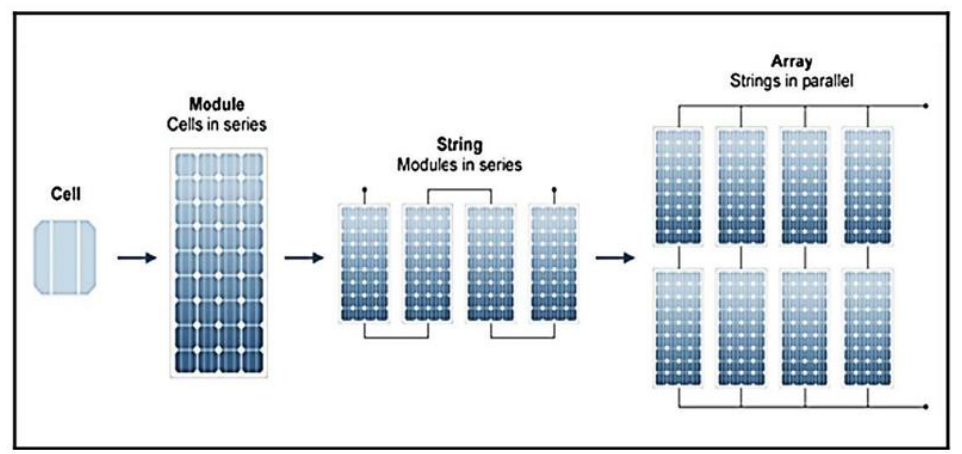

Gambar 2. Komposisi Susunan Photovoltaic (3)

\subsubsection{Inverter}

Inverter adalah perangkat elektrik yang digunakan untuk mengubah arus listrik searah (DC) menjadi arus listrik bolak balik (AC). Inverter mengkonversi DC dari perangkat seperti batere, panel surya / solar cell menjadi AC. Penggunaan inverter dari dalam Pembangkit Listrik Tenaga Surya (PLTS) adalah untuk perangkat yang menggunakan AC (Alternating Current).

\subsubsection{Konfigurasi Sistem PLTS}

Terdapat 2 jenis konfigurasi PLTS yaitu Standalone photovoltaic dan Grid connected photovoltaic. 
- Stand Alone Photovoltaic

- Grid Connected Photovoltaic

Grid Connected PV System merupakan solusi Green Energy bagi penduduk perkotaan baik perumahan ataupun perkantoran. Sistem PLTS ini menggunakan Modul Surya (Photovoltaic Module) untuk menghasilkan listrik yang ramah lingkungan dan bebas emisi.

Dalam penelitian ini, konfigurasi yang digunakan adalah Grid Connected PV.

\subsubsection{Analisis Interkoneksi dengan software ETAP}

\subsubsection{Aliran Daya (Load Flow)}

Analisis aliran daya merupakan studi dasar dalam menganalisis suatu sistem Tenaga Listrik, baik untuk perencanaan maupun operasi. Secara umum tujuan analisis aliran daya adalah:

- Untuk memeriksa tegangan masing-masing bus

- Untuk mengetahui jatuh tegangan dan rugi-rugi daya pada sistem tenaga listrik

- Untuk memeriksa semua kemampuan peralatan yang ada dalam sistem apakah cukup besar untuk menyalurkan daya yang diinginkan

\subsubsection{Hubung Singkat (Short Circuit)}

Istilah gangguan hubung singkat digunakan untuk menjelaskan suatu hubungan singkat. Untuk mengatasi gangguan tersebut, perlu dilakukan analisis hubung singkat sehingga sistem Proteksi yang tepat pada Sistem Tenaga Listrik dapat ditentukan. Analisis hubung singkat adalah analisis yang mempelajari kontribusi arus gangguan hubung singkat yang mungkin mengalir pada setiap cabang didalam sistem (di jaringan distribusi, transmisi, trafo tenaga atau dari pembangkit) sewaktu gangguan hubung singkat yang mungkin terjadi di dalam sistem tenaga listrik. (4)

\subsubsection{Rugi Daya (Drop Voltage)}

Pada konduktor pasti memiliki nilai impedansi dan sehingga setiap kali arus mengalir melalui kabel tersebut, akan ada jatuh tegangan disepanjang kabel, yang dapat diturunkan dengan Hukum Ohm. Penurunan tegangan tersebut tergantung pada dua hal, yaitu:

- Aliran arus melalui kabel - semakin tinggi arus, semakin besar tegangan drop

- Impedansi konduktor - semakin besar impedansi, semakin besar tegangan drop Besarnya rugi tegangan dapat dinyatakan sebagai berikut :

$$
\begin{aligned}
& \Delta V=I . R \cdot \cos \varphi+I . X \cdot \sin \varphi(\text { volt }) \\
& \Delta V=I x Z
\end{aligned}
$$

Keterangan :

$\Delta \mathrm{V} \quad=$ Jatuh tegangan (volt)

I = Arus yang mengalir (Ampere)

$\mathrm{R}=$ Tahanan Saluran (Ohm)

$\mathrm{X} \quad=$ Reaktansi (Ohm)

$\Phi=$ Sudut dari factor daya beban

$\mathrm{Z} \quad=\mathrm{R}+\mathrm{jX}=$ impedansi saluran 
Jatuh tegangan pada saluran adalah selisih antara tegangan pada pangkal pengiriman dengan tegangan pada ujung penerimaan tenaga listrik. (5)

\subsubsection{Parameter Ekonomi}

Dalam melakukan analisis ekonomi erhadap sistem PLTS terdapat beberapa indikator yang sering digunakan, yaitu Payback Period analysis, Net Present Value (NPV), Internal Rate of Return (IRR) analysis. Selain itu, dalam penentuan tarif listrik suatu pembangkit terdapat beberapa komponen seperti komponen $A, B, C, D$ dan $E$.

\subsection{Metodologi Penelitian}

Penelitian ini dilakukan dengan mengumpulkan literatur terlebih dahulu, setelah itu dilakukan pengumpulan data yang akan di analisis. Data tersebut adalah :

- Data lokasi PLTS

- Data Gardu Induk sebagai calon titik interkoneksi (GI Cileungsi) Kerangka penelitian yang digunakan adalah sebagai berikut:

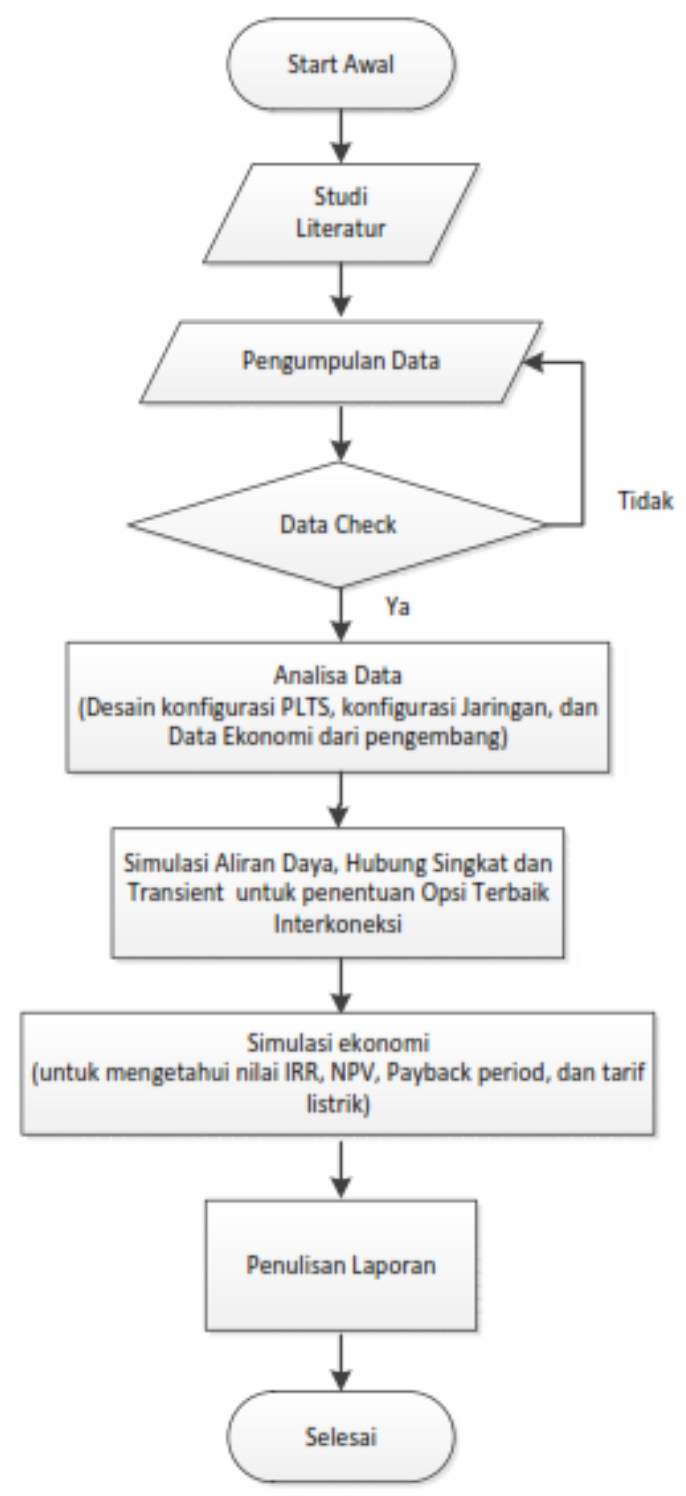

Gambar 3. Kerangka Penelitian 


\section{HASIL DAN PEMBAHASAN}

Proyek Pembangkit Listrik Tenaga Surya Cileungsi $1 \mathrm{MW}$ ini berlokasi di area pabrik kertas milik PT. Aspex Kumbong, yang beralamatkan desa Dayeuh, kec. Cileungsi, kab. Bogor. Dengan koordinat 6 $6^{\circ} 26^{\prime} 1.20$ "S dan $106^{\circ} 57^{\prime} 2.6^{\prime \prime} \mathrm{E}$ dalam kondisi topografi dekat GI Cileungsi milik PLN, datar tanpa pohon dengan ketinggian $78 \mathrm{~m}$ di atas permukaan laut rata-rata.

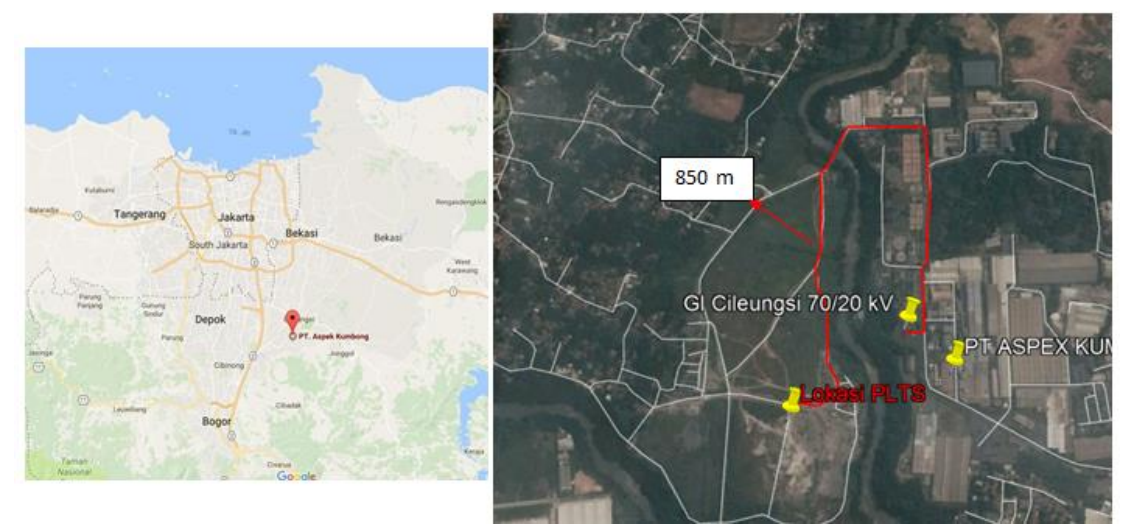

Gambar 4. Lokasi PLTS Cileungsi $1 \mathrm{MWp}$

Intensitas insolation total tahunan untuk area target yang diharapkan dari proyek adalah 1,654.6 kWh / m2, dengan suhu rata-rata tahunan 24,18․ Data ini didasarkan pada perangkat lunak $P V *$ SYST.

\subsection{Peralatan Utama yang digunakan adalah modul surya dan inverter.}

Tabel 1. Spesifikasi Solar Module

\begin{tabular}{|l|c|c|}
\hline Manufacturer & $\begin{array}{c}\text { JA solar holdings } \\
\text { Co., Ltd. }\end{array}$ & Unit \\
\hline \multicolumn{3}{|c|}{ Electrical data } \\
\hline Cell type & Si polycrystalline & \\
\hline Number of cells & 72 & \\
\hline $\begin{array}{l}\text { Number of bypass } \\
\text { diodes }\end{array}$ & 3 & \\
\hline \multicolumn{3}{|c|}{ Mechanical data } \\
\hline Width & 991 & $\mathrm{~mm}$ \\
\hline Height & 1956 & $\mathrm{~mm}$ \\
\hline Depth & 5 & $\mathrm{~mm}$ \\
\hline Frame width & 40 & $\mathrm{~mm}$ \\
\hline Weight & 26 & $\mathrm{Kg}$ \\
\hline \multicolumn{2}{|c|}{ Characteristic cs at STC } \\
\hline MPP voltage & 37.38 & $\mathrm{~V}$ \\
\hline MPP current & 8.56 & $\mathrm{~A}$ \\
\hline Nominal output & 320 & $\mathrm{~W}$ \\
\hline Open circuit Voltage & 46.22 & $\mathrm{~V}$ \\
\hline Short-circuit current & 9.06 & $\mathrm{~A}$ \\
\hline
\end{tabular}


Vol. 9, No. 2, Desember 2019, P-ISSN 2356-1505, E-ISSN 2656-9175

https://doi.org/10.33322/sutet.v9i2.901

Tabel 2. Spesifikasi Inverter

\begin{tabular}{|c|c|c|}
\hline Manufacture & ABB & Unit \\
\hline DC power rating & 51.2 & $\mathrm{~kW}$ \\
\hline AC power rating & 60 & $\mathrm{~kW}$ \\
\hline Mac. DC power & 70 & $\mathrm{~kW}$ \\
\hline Max AC power & 60 & $\mathrm{~kW}$ \\
\hline
\end{tabular}

Tabel 3. Asumsi Model Solar

\begin{tabular}{|l|l|l|}
\hline \multicolumn{1}{|c|}{ Divisi } & \multicolumn{1}{|c|}{ Deskripsi } & Keterangan \\
\hline Target Area & $\begin{array}{l}\text { PT Aspex Kumbong, Gn. Putri, } \\
\text { Bogor }\end{array}$ & \\
\hline Weather Data Sources & Meteonom 7.2 & \\
\hline Latitude & $-6.433889^{\circ}$ & \\
\hline Longitude & $102.951111^{\circ}$ & \\
\hline Installation Method & Fixed Tilt & \\
\hline Capacity & 1 MWp & \\
\hline System Type & Grid Connected & \\
\hline Available Area & Approx. $10,000 \mathrm{~m}^{2}$ & \\
\hline Series x Parallel & $6 \times 30$ & 3240 sheets \\
\hline Array Azimuth & Due North & \\
\hline Module & 320 Wp & 18 sets \\
\hline Cell Type & Poly-crystalline & \\
\hline Inverter & $60 \mathrm{~kW}$ & \\
\hline
\end{tabular}

\subsection{Hasil Simulasi PLTS}

Hasil energi teoritis dan simulasi untuk tahun pertama operasi dihitung senilai 1.467.730 kWh. Tabel di bawah ini menunjukkan iradiasi bulanan dan perkiraan output daya PLTS.

Tabel 4. Energi Hasil Simulasi Bulanan

\begin{tabular}{|c|c|c|c|}
\hline Waktu & $\begin{array}{c}\text { Iradiasi Horizontal } \\
\left(\mathrm{kWh} / \mathrm{m}^{2}\right)\end{array}$ & Temperature $\left({ }^{\circ} \mathrm{C}\right)$ & $\begin{array}{c}\text { PV Generated Output AC } \\
\text { Grid (kWh) }\end{array}$ \\
\hline Tahun & $1.654,60$ & 24,18 & $1.467 .730,00$ \\
\hline Jan & 106,37 & 23,88 & 89,30 \\
\hline Feb & 108,06 & 23,54 & 92,75 \\
\hline Mar & 139,36 & 24,19 & 122,05 \\
\hline Apr & 144,30 & 24,26 & 129,46 \\
\hline Mei & 147,27 & 24,70 & 136,12 \\
\hline Jun & 138,80 & 24,08 & 130,76 \\
\hline Jul & 148,91 & 23,95 & 139,50 \\
\hline Aug & 159,13 & 24,25 & 145,14 \\
\hline Sep & 155,49 & 24,28 & 137,46 \\
\hline Okt & 149,52 & 24,78 & 128,27 \\
\hline Nov & 126,55 & 24,14 & 107,39 \\
\hline Des & 130,85 & 24,05 & 109,53 \\
\hline
\end{tabular}




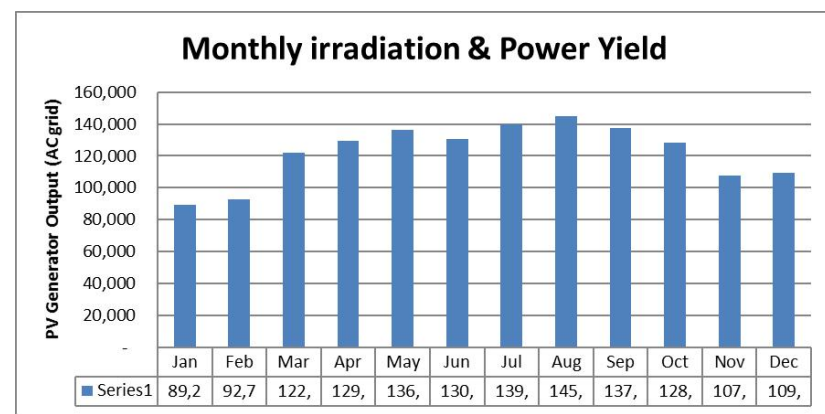

Gambar 5. Output Daya Sistem PV Kapasitas 1 MWp

Berdasarkan data lokasi, spesifikasi peralatan utama, dan hasil simulasi maka dapat digambarkan secara sederhana plant layout dari PLTS Cileungsi $1 \mathrm{MWp}$ ini pada gambar di bawah ini.

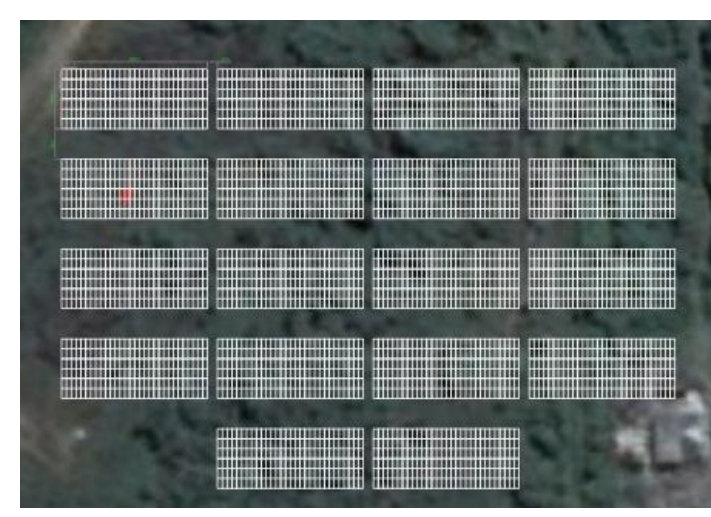

Gambar 6. Gambaran Sederhana Plant Layout PLTS Cileungsi $1 \mathrm{MWp}$

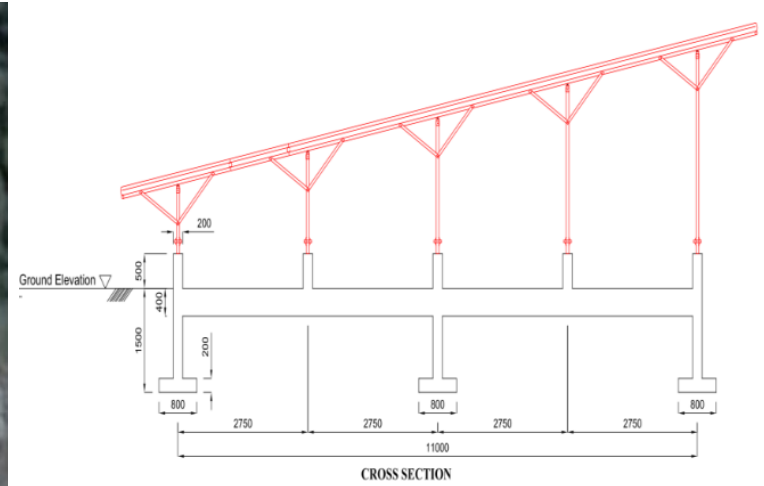

Gambar 7. Gambaran Tampak Samping Pemasangan PLTS Cileungsi $1 \mathrm{MWp}$

Berdasarkan gambar di atas, maka perhitungan jumlah modul dan array adalah sebagai berikut :

Jumlah array dan modul $\quad=18$ array, 180 modul

Kapasitas listrik dalam 1 module $\quad=320 \mathrm{~W}$

Jumlah daya yang didapat $\quad=18 \times 180 \times 320 \mathrm{~W}=1.036 .800 \mathrm{~W} \approx 1,036$

$\mathrm{kW} \approx 1 \mathrm{MW}$

\subsection{Analisis Konfigurasi Jaringan Distribusi untuk Interkoneksi PLTS Cileungsi ke} Sistem Grid

Terdapat 2 opsi titik interkoneksi PLTS 1 MWp ini yaitu pada GI Cileungsi sejauh 850 meter, atau pada gardu PRF (Gl Cibinong). Namun sebelum analisis lebih jauh, dilakukan pemilihan opsi terbaik terlebih dahulu dengan tabel berikut.

Tabel 5. Perbandingan Opsi 1 dan 2 Interkoneksi PLTS Cileungsi

\begin{tabular}{|c|l|l|l|l|c|}
\hline \multirow{2}{*}{ No. } & \multicolumn{2}{|c|}{ Hal yang Ditinjau } & \multicolumn{2}{|c|}{ Opsi 1 (di Gl Cileungsi) } & \multicolumn{2}{|c|}{ Opsi 2 (TD PRF) } \\
\cline { 3 - 6 } & \multicolumn{1}{|c|}{ Deskripsi } & Nilai & Deskripsi & Nilai \\
\hline 1 & $\begin{array}{l}\text { Jarak dari PLTS ke titik } \\
\text { interkoneksi (Porsi nilai } \\
\text { 25\%) }\end{array}$ & 850 meter & 15 & 350 meter & 25 \\
\hline
\end{tabular}


Vol. 9, No. 2, Desember 2019, P-ISSN 2356-1505, E-ISSN 2656-9175

https://doi.org/10.33322/sutet.v9i2.901

\begin{tabular}{|c|c|c|c|c|c|}
\hline 2 & $\begin{array}{l}\text { Beban pada titik } \\
\text { interkoneksi } \\
\text { nilai 25\%) }\end{array}$ & $18,1 \mathrm{MW}$ & 25 & 3,19 MW & 25 \\
\hline 3 & $\begin{array}{l}\text { Fasilitas pada titik } \\
\text { penyambungan (Porsi nilai } \\
25 \% \text { ) }\end{array}$ & $\begin{array}{l}\text { Telah tersedia spare } \\
\text { untuk penyambungan } \\
\text { PLTS } 1 \mathrm{MW}\end{array}$ & 25 & $\begin{array}{l}\text { Harus membangun } \\
\text { fasilitas } \\
\text { penyambungan }\end{array}$ & 15 \\
\hline 4 & $\begin{array}{l}\text { Kemampuan sistem untuk } \\
\text { backup saat PLTS } \\
\text { mengalami gangguan } \\
\text { (Porsi nilai 25\%) }\end{array}$ & $\begin{array}{l}\text { Jika PLTS terganggu, } \\
\text { maka GI bisa } \\
\text { langsung back-up } \\
\text { beban dari grid melalui } \\
\text { trafo 1, dan } \\
\text { pengontrolan PLTS } \\
\text { oleh PLN juga lebih } \\
\text { mudah }\end{array}$ & 25 & $\begin{array}{l}\text { Jika PLTS terganggu, } \\
\text { maka beban } \\
\text { penyulang } \\
\text { membutuhkan suplai } \\
\text { dari GI yang terletak } \\
\text { cukup jauh sehingga } \\
\text { membutuhkan waktu }\end{array}$ & 15 \\
\hline \multicolumn{2}{|c|}{ Jumlah nilai } & \multicolumn{2}{|l|}{90} & \multicolumn{2}{|l|}{80} \\
\hline
\end{tabular}

Dari tabel 4.8, disimpulkan bahwa opsi 1 merupakan pilihan terbaik untuk interkoneksi PLTS Cileungsi $1 \mathrm{MWp}$ ke grid sistem. Maka dari itu, analisis selanjutnya akan langsung mengkaji mengenai konfigurasi jaringan distribusi untuk interkoneksi PLTS Cileungsi ke GI Cileungsi.

Saluran kabel tegangan menengah (SKTM) dan saluran udara tegangan menengah (SUTM) memiliki kekurangan dan kelebihan masing-masing. Mengingat jarak antara PLTS dan GI tidak jauh (850m) maka pemilihan SKTM lebih diutamakan, selain itu juga daerah PLTS ini adalah daerah pabrik dimana hampir semua jaringan distribusinya adalah SKTM.

Sesuai dengan rencana titik interkoneksi pengembang akan membangun JTM baru dari PLTS Cileungsi dengan diameter penghantar 1 × $240 \mathrm{~mm} 2$ dengan kemampuan arus yang melewati penghantar seperti pada tabel dibawah ini:

Tabel 6. KHA Kabel yang Digunakan (3)

\begin{tabular}{|c|c|c|c|c|c|}
\hline \multirow{3}{*}{$\begin{array}{l}\text { JENIS } \\
\text { KABEL }\end{array}$} & \multirow{3}{*}{$\begin{array}{l}\text { PENAMPANG } \\
\text { NOMINAL } \\
\text { MM }^{2}\end{array}$} & \multicolumn{4}{|c|}{ KUAT HANTAR ARUS } \\
\hline & & \multicolumn{2}{|c|}{$\begin{array}{l}\text { TEGANGAN KERJA } \\
6 / 10 \mathrm{kV}\end{array}$} & \multicolumn{2}{|c|}{$\begin{array}{l}\text { TEGANGAN KERJA } \\
9 / 15 \mathrm{kV} \& 12 / 20 \mathrm{KV}\end{array}$} \\
\hline & & $\begin{array}{l}\text { DITANAH } \\
\text { (A) }\end{array}$ & $\underset{A}{\text { DI UDARA }}$ & $\begin{array}{l}\text { DI TANAH } \\
\text { (A) }\end{array}$ & DI UDARA \\
\hline 1 & 2 & 3 & 4 & 5 & 6 \\
\hline & $\begin{array}{l}35 \\
50\end{array}$ & 164 & 173 & 164 & 173 \\
\hline & 50 & 194 & 206 & 194 & \\
\hline N2XSEY & 70 & 236 & 257 & 236 & 257 \\
\hline \multirow{5}{*}{$\begin{array}{l}\text { N2XSY } \\
\text { NSXCY }\end{array}$} & 95 & 293 & 313 & 285 & 313 \\
\hline & 120 & $\begin{array}{l}322 \\
362\end{array}$ & 360 & 322 & $\begin{array}{l}360 \\
410\end{array}$ \\
\hline & $\begin{array}{l}150 \\
185\end{array}$ & 362 & $\begin{array}{l}410 \\
469\end{array}$ & 362 & $\begin{array}{l}410 \\
469\end{array}$ \\
\hline & 185 & $\begin{array}{l}409 \\
474\end{array}$ & $\begin{array}{l}469 \\
553\end{array}$ & 409 & $\begin{array}{l}469 \\
553\end{array}$ \\
\hline & $\begin{array}{l}240 \\
300\end{array}$ & $\begin{array}{l}474 \\
533\end{array}$ & $\begin{array}{l}553 \\
629\end{array}$ & $\begin{array}{l}474 \\
533\end{array}$ & $\begin{array}{l}553 \\
629\end{array}$ \\
\hline & & 148 & 161 & 146 & 161 \\
\hline & 70 & 184 & 199 & 179 & 204 \\
\hline NA2XSEY & 95 & 220 & 242 & 214 & 242 \\
\hline \multirow{5}{*}{ NA2XCY } & 120 & 250 & 280 & 246 & 282 \\
\hline & 150 & 281 & 318 & 272 & 319 \\
\hline & & 319 & 365 & 308 & 365 \\
\hline & 240 & 370 & 425 & 358 & 425 \\
\hline & 300 & 420 & 481 & 398 & 481 \\
\hline
\end{tabular}

$$
\begin{array}{ll}
\text { Derating faktor } & =0,9 \times 362 \mathrm{~A}=325,8 \mathrm{~A} \\
\text { Daya yang } & =\mathrm{V} \times I \times \cos \oplus \times \sqrt{3} \\
\text { mampu ditampung } & =20 \mathrm{kV} \times 325,8 \mathrm{~A} \times 0,8 \times \sqrt{ } 3 \\
& =9028,8 \mathrm{~kW} \approx 9 \mathrm{MW}
\end{array}
$$




\subsection{Simulasi ETAP Aliran Daya, Hubung Singkat, dan Transient Interkoneksi PLTS Cileungsi ke GI Cileungsi}

3.4.1. Aliran Daya

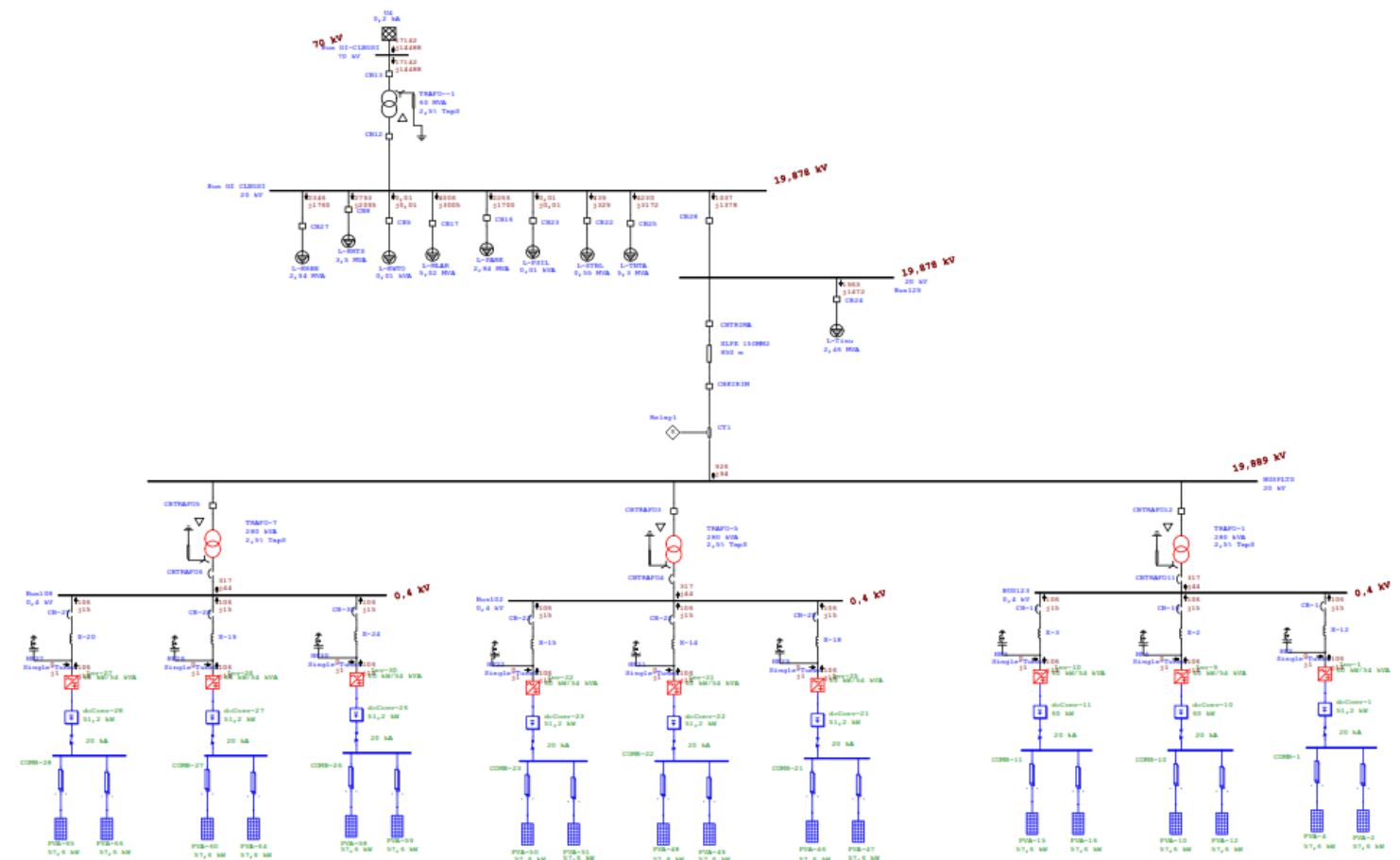

Gambar 8. Hasil Simulasi Aliran Daya

Tabel 7. Hasil Simulasi Aliran Daya

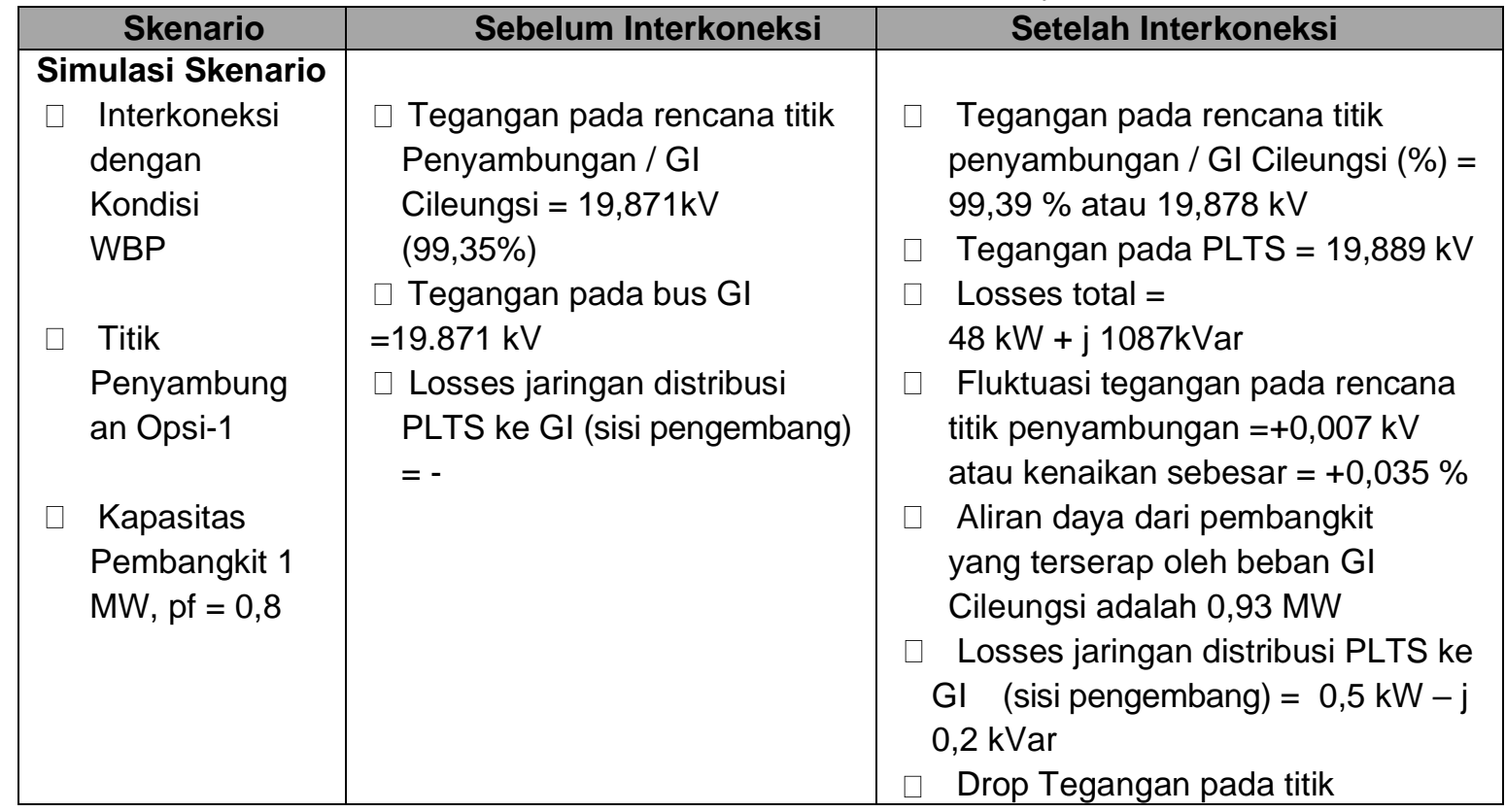

\subsubsection{Hubung Singkat}

Dari gambar hasil simulasi hubung singkat terlihat bahwa arus hubung singkat yang terjadi saat terjadi gangguan pada bus PLTS tidak lebih dari 16kA (hanya 3,6kA). Hal ini menunjukkan bahwa desain konfigurasi yang direncanakan tidak menimbulkan arus 
gangguan hubung singkat yang melebihi kapasitas peralatan. Sehingga aman bagi peralatan eksisting PLN dan peralatan pengembang.

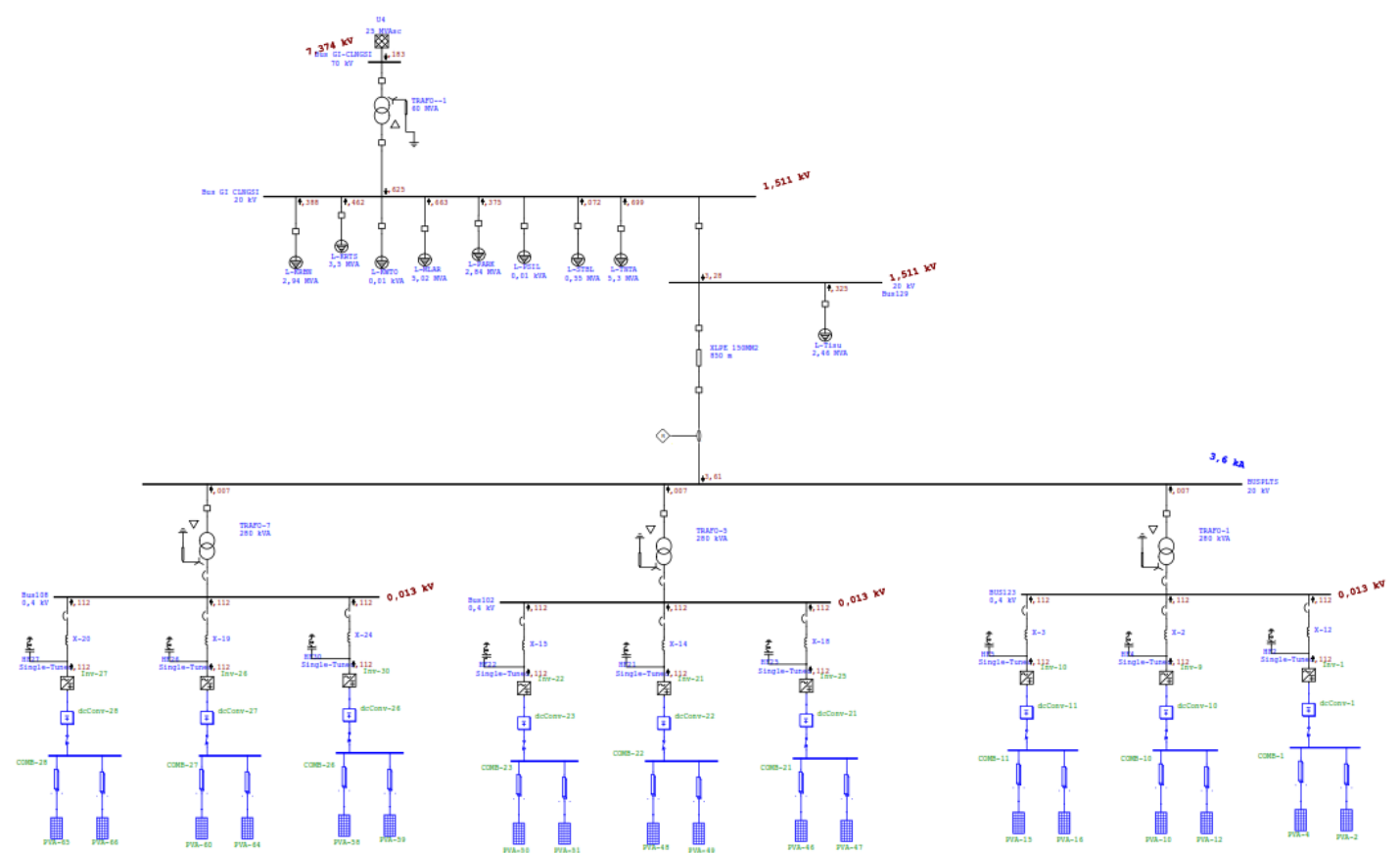

Gambar 9.Hasil Simulasi Hubung Singkat pada Bus PLTS

\subsubsection{Transient}

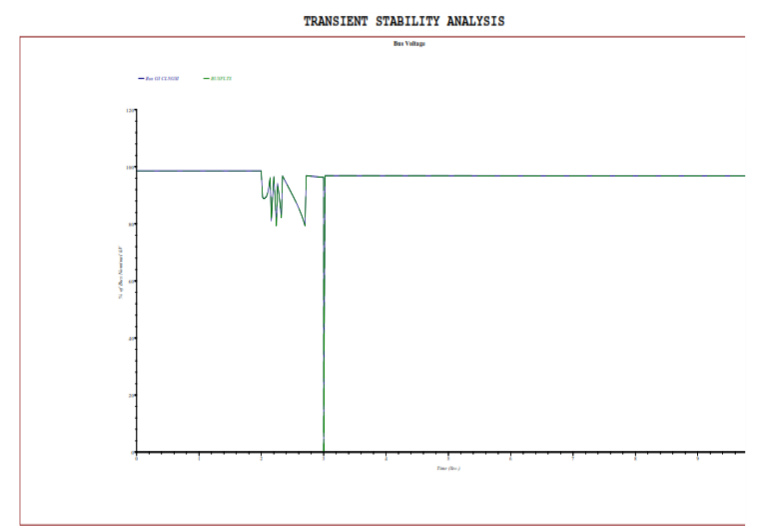

Gambar 10. Hasil Simulasi Transient (Bus Voltage)

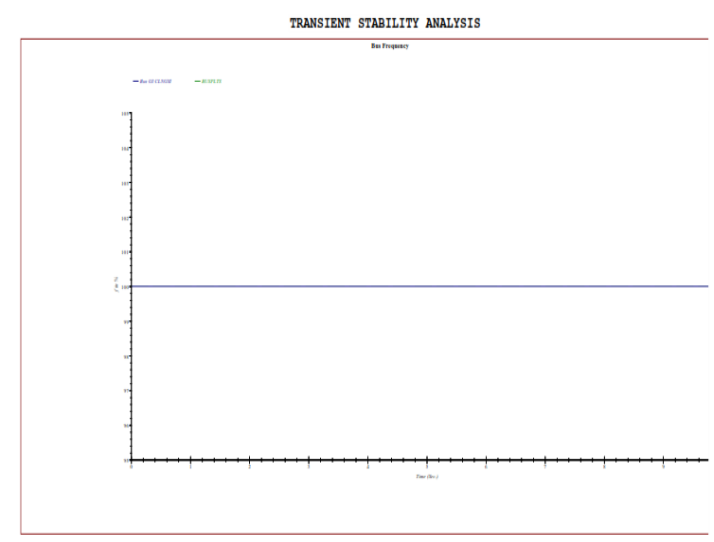

Gambar 11. Hasil Simulasi Transient (Bus frequency)

Dari ke-tiga simulasi di atas (aliran daya, hubung singkat dan transient) dapat disimpulkan bahwa desain dasar dan konfigurasi jaringan yang telah direncanakan sebelumnya tidak menimbulkan kerugian bagi PLN dan pengembang baik dari sisi jatuh tegangan, rugi-rugi daya, arus hubung singkat yang terjadi dan kestabilan sistem.

\subsection{Analisis Sisi Ekonomi}

Data untuk analisis ekonomi dari pengembangan PLTS 1MW Cileungsi ini di dapat dari hasil diskusi bersama dengan pihak calon EPC. 
Dari tabel 8 berikut didapat beberapa hal sebagai berikut :

- Nilai electricity tariff nya adalah 0,06884 USD/kWh atau Rp 974,09

- Nilai IRR Project nya adalah $6,68 \%$

- Nilai NPV nya adalah $123.845,82$ USD

- Payback period adalah 11 tahun

Tabel 8. Hasil Simulasi Ekonomi dari Pengembangan PLTS 1 MW

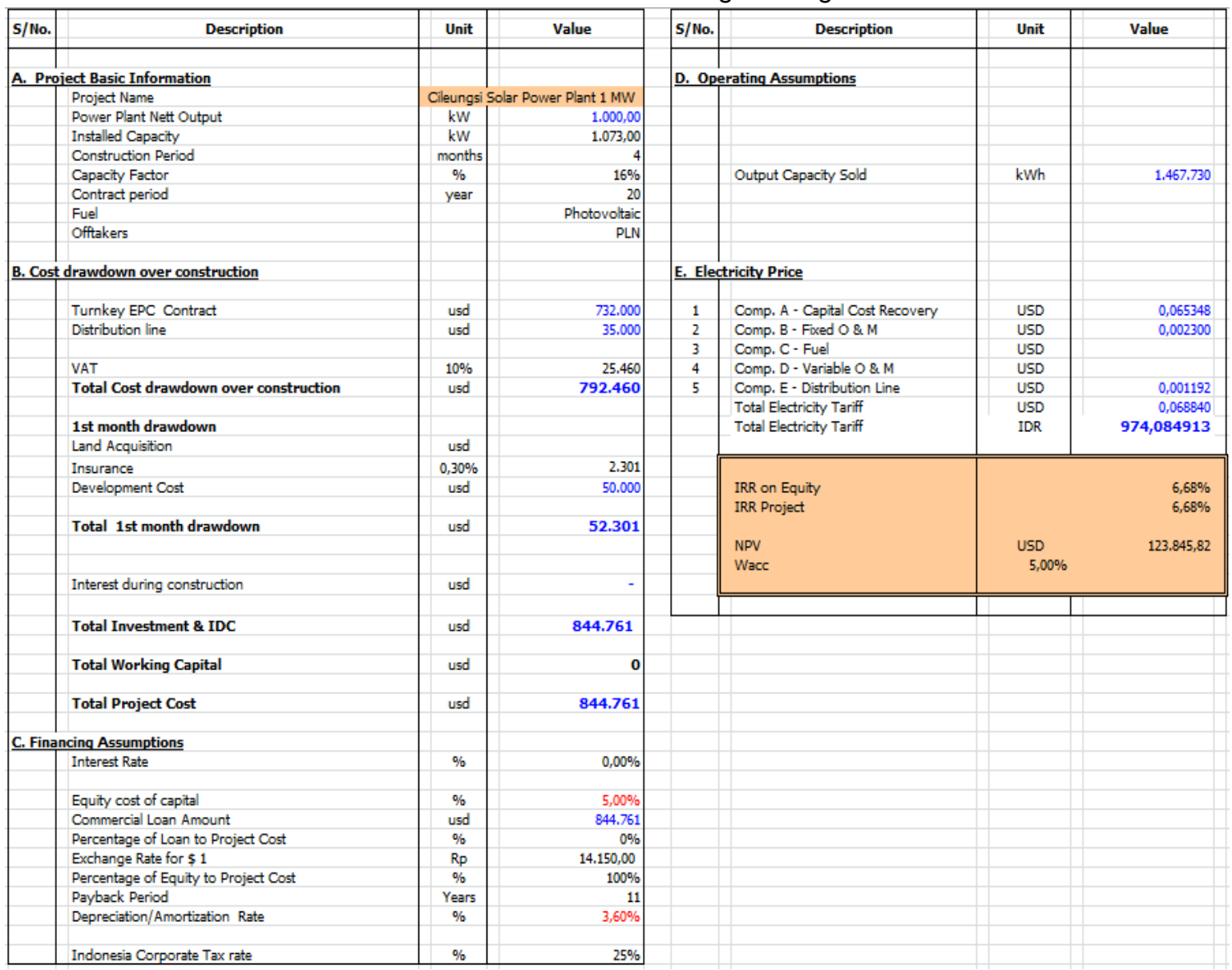

\section{KESIMPULAN DAN SARAN}

Berdasarkan kajian analisis interkoneksi PLTS Cileungsi $1 \mathrm{MWp}$ pada sistem distribusi PLN Area Cileungsi dapat disimpulkan sebagai berikut :

a) PLTS Cileungsi adalah pembangkit EBT yang ramah lingkungan dan diharapkan dapat mengurangi penggunaan bahan bakar fosil.

b) Kapasitas PLTS direncanakan $1 \mathrm{MWp}$ dengan konfigurasi desain 18 array, dimana 1 array terdiri dari 180 module (6 seri x 30 paralel). Module PLTS yang digunakan memiliki kapasitas 320 watt.

c) Titik sambung yang terpilih dari hasil analisis interkoneksi adalah pada opsi I (Ke Usulan Gl Cileungsi dengan koordinat 6²5'37.00"S, 10657'10.00"E, dengan jarak dari pembangkit sejauh $850 \mathrm{~m}$ ). Jenis penghantar yang digunakan adalah XLPE $150 \mathrm{~mm}^{2}$ dengan sirkuit tunggal.

d) Interkoneksi PLTS Cileungsi tidak memberikan dampak negatif terhadap sistem distribusi milik PLN dan juga bagi pengembang karena drop tegangan 
tidak melampaui batas maksimum $\pm 5 \%$ yaitu hanya $0,055 \%$, dan rugi-rugi daya hanya $0,05 \%$, nilai arus hubung singkat yang terjadi hanya $3,8 \mathrm{kA}$ tidak melebihi kapasitas peralatan eksisting yaitu $16 \mathrm{kA}$, serta jika terjadi gangguan pada PLTS maka tegangan kembali stabil tidak lebih dari 1 detik.

e) Nilai electricity tariff yang diperoleh dari hasil simulasi adalah 6,884 cent USD/kWH dimana nilai ini masih dibawah BPP setempat untuk daerah Jawa Barat yaitu 6,91 cent USD/kWh. Nilai IRR Project nya adalah 6,68\% sedangkan NPV nya adalah 123.845,82 USD dengan payback period pada tahun ke-11.

Disarankan agar dilakukan kajian yang lebih detail untuk melihat dampak interkoneksi PLTS Cileungsi terhadap sistem PLN baik dari sisi teknis maupun finansialnya.

\section{UCAPAN TERIMAKASIH}

Diucapkan terimakasih kepada PT Indopower International atas semua bantuan dan dukungannya baik untuk penggunaan data dan juga diskusi selama pengerjaan penelitian tesis ini berlangsung.

\section{DAFTAR PUSTAKA}

[1] Engineering design development of 52,5 KiloWatt peak solar photovoltaic system for industrial Rooftop building. Damiri, Dhami Johar. 2019, Journal of PhysicsÖ Conference Series, hal. 1.

[2] Pemanfaatan Energi Surya. Widayana, Gede. 2012, UNDIKSHA, hal. 41.

[3] International, PT Indopower. Studi Kelayakan PLTS Cileungsi 1 MW. Jakarta : Indopower International, 2018.

[4] Kholis, Ikhwannul. wordpress.com. [Online] $12 \quad 11 \quad 2013$. https://ikkholis27.wordpress.com/2013/11/12/analisis-gangguan-hubung-singkat/.

[5] Analisis Sistem Distribusi 20 kV untuk Memeperbaiki Kinerja dan Keandalan Sistem Distribusi Menggunakan Electrical Transient Analisys Program. Tanjung, Abrar. 2012, Seminar Nasional Teknologi Informasi Komunikasi dan Indsutri (SNTIKI) 4, hal. 394.

[6] Hankins, Mark. Stand Alone Solar Electric System. London, Washington DC : Earthscan, 2010.

[7] Ross, S. Fundamental of Corporate Finance. New York : McGraw Hill, 2010.

[8] Suripto, Slamet. Sistem Tenaga Listrik. [pengar. buku] Slamet suripto. Sistem Tenaga Listrik. Yogyakarta : s.n., 2016, hal. 1.

[9] Biaya Dalam Pembangkitan Tenaga Listrik. Watergius. 2011, Watergius's Journal.

[10] Elgerd. Electric Energy System Theory. New York : McGraw-Hill Book Company, 1982.

[11] Marsudi, Djiteng. Pembangkitan Energi Listrik. Jakarta : Erlangga, 2005.

[12] Dunlop, Solar Jim. ecgllp.com. [Online] 2012. [Dikutip: Thuesday January 2020.] https://ecgllp.com/files/5614/0200/1304/8-Inverters.pdf. 